Open Access

\title{
Perception of women entrepreneurs to accessing bank credit
}

\author{
Touheda Yasmin Chowdhury ${ }^{1}$, Aysa Yeasmin ${ }^{1}$ and Zobayer Ahmed ${ }^{2^{*}}$
}

\author{
* Correspondence: \\ ecozobayer@gmail.com \\ 2Department of Economics \& \\ Banking, International Islamic \\ University Chittagong, Chittagong, \\ Bangladesh \\ Full list of author information is \\ available at the end of the article
}

\begin{abstract}
Women entrepreneurs play a substantial role in the sustainable economic development of various developed as well as developing countries in the world. In Bangladesh, the contribution of women entrepreneurs is still insignificant compared to other entrepreneurship due to a number of barriers to their financial inclusion. The current study tried to find out the problems faced with and the opinion of women entrepreneurs regarding the finance from commercial banks. The study used primary data from a sample survey, Key Informant Interview (KII) and in-depth interviews with the selected women entrepreneurs from Sylhet city of Bangladesh to meet the research objectives. Using Exploratory Factor Analysis (EFA), the study brings to life the fact that women entrepreneurs are reluctant to take the loan from banks because they have to face a number of problems there. Some of the major problems they faced are- collateral requirements, terms and conditions of bank loan, business characteristics and some other institution-specific problems to get access to bank finance. The findings of the study can aid the commercial banks in formulating their strategic decision about financing women entrepreneurs. In addition, this study indicates the way forward for the authoritative and supporting organizations of women entrepreneurs to formulate their action plans for the development of women entrepreneurship.
\end{abstract}

Keywords: Women entrepreneurship, Bank financing, Entrepreneurship development, Bank loan, Bangladesh

\section{Introduction}

Entrepreneurship refers to starting a new business or venture. Schumpeter defines an entrepreneur as, a person who is willing and able to convert an original idea and invention into a successful innovation (Schumpeter and Backhaus, 2003). A person who wants to be a promising entrepreneur should possess the self-reliance and ability to deal with an unpredictably adverse circumstance. To receive the utmost contribution from the entrepreneurs for the progress of the society and the nation as a whole, it is indispensable to support them financially and socially. Inadequate capital for starting a new business is one of the leading problems for the women entrepreneurs in Bangladesh. Usually, women initiate their business with limited money collected by savings from family expenditure, relatives or other sources. To get a bank loan, women are required to put collateral. But they do not have sufficient fixed capital to place as collateral or a guarantor to get a small loan from the bank.

(c) The Author(s). 2018 Open Access This article is distributed under the terms of the Creative Commons Attribution 4.0 International License (http://creativecommons.org/licenses/by/4.0/), which permits unrestricted use, distribution, and reproduction in any medium, provided you give appropriate credit to the original author(s) and the source, provide a link to the Creative Commons license, and indicate if changes were made. 
Involvement in business by women entrepreneur is advancing throughout the world. In the past year, 163 million women were starting businesses across 74 economies worldwide, while 111 million were running established businesses (GEM, 2011). The contribution of women to the GDP growth of Bangladesh is 34\% (BER, 2016). Women enter the business for not only earning money, survival and rising of living standards but also to develop their careers and establish their rights into the society and the nation. Empirical studies demonstrates that women confront obstacles not only in starting their venture but also in running it (Parvin, Rahman, and Jia, 2012). Some studies found that though women entrepreneurs are satisfied with their enterprise, they still encounter difficulties resulted from non-availability of different supportive services, access to finance, society and family (Hanifa et al., 2011). On the other hand, a business owned by a single woman are less likely to start its operation after obtaining bank loan due to liquidity constraints, and the public policy programme specially targeted liquidity-constrained women were effective in accelerating rate of women entrepreneurs (Sauer and Wilson, 2016).

Abundant studies on the challenges of women entrepreneurship development have been conducted in Bangladesh and other countries. Most of the studies have found that women entrepreneurs principally encounter complexities regarding family, society, financial access and support services (Amzad, Kamal, Asif, \& Rana, 2009; Coleman, 2000). Some studies specifically focus on the financing behaviour of the women entrepreneurs (Ullha et al., 2012). There has not been any research conducted on the perception of women entrepreneurs specifically regarding the role of commercial banks.

In this study, we attempted to comprehend the perception of women entrepreneurs about the commercial bank loan and supporting services. The current study was conducted on women entrepreneurs of Sylhet city in Bangladesh. According to GEM (2011), the opportunities to launch businesses in Sylhet are significantly nascent. There are significantly better business start-up opportunities in Sylhet region along with the lowest start-up skill among the inhabitants comparing to all other regions of Bangladesh. In choosing the career, the residents of Sylhet consider establishing a business as a striking choice (GEM, 2011).

\section{Literature review}

\section{An overview of financial system in Bangladesh}

The financial system of Bangladesh is comprised of 57 scheduled banks, 6 non-scheduled banks, 31 NBFIs, 18 life insurances, 44 non-life insurances, stock exchanges, stock dealers and brokers, asset management companies, credit rating agencies, 599 microfinance institutions and their regulatory authorities like Bangladesh Bank, Insurance Development and Regulatory Authority, Securities and Exchange Commission, Micro Credit Regulatory Authority.

The central bank of Bangladesh does not directly regulate the interest rates since the post-1990's reform era, although different kinds of banks are working in the country. However, a more competitive as well as efficient banking system is yet to be developed. Recent corruption in state-owned banks proves that the entire banking system of the country characterized by mismanagement and straight intervention from government in power. Further, the private commercial banks do not set the interest rate in a 
competitive manner (Nguyen, Islam, \& Ali, 2011). However, studies revealed that the service quality standard is vital for customer satisfaction in private commercial banks of Bangladesh that depends significantly on the reliability, responsiveness, tangibility, assurance, and empathy significantly and positively influenced customer attitudes in terms of satisfaction (R. Karim \& Chowdhury, 2014).

\section{Background of women entrepreneurship in Bangladesh}

There is no well-accepted definition of entrepreneurship. The definition varies from one to another because business activities vary based on its nature. Normally entrepreneur is a person who starts or organize a commercial enterprise that involves financial risk (Barber, 1998). Entrepreneurship encompasses a wide range of activities including creation of an organization, creation of new product or production process, introducing advance quality, innovation of marketing approach, etc. (Gartner, 1988). Thus entrepreneurship stands on the devotion of time, skill, effort and taking a financial, social and physical risk to create something of value and reap the monetary reward and personal satisfaction (Hirsch \& Peters, 1989).

Bangladesh is an overpopulated country with limited land and resources. Nearly half of the population of the country are female whose role in the society is either as wife or mother. As a result, their contribution to the economy is not counted when calculating GDP or GNP of the country (BBS, 2016). For the last few decades, women have been breaking those traditional thoughts and making their contribution to economic development. Entrepreneurship is getting acceptance to both rural and urban women. Rural women mostly enter into business for economic solvency as they have poor educational qualification for accessing the job market. Urban women are becoming entrepreneur not only for the economic benefit but also for career and professional development. In the context of Sub-Saharan Africa, Asuming et al. (2018) suggest that policies related to financial inclusion should target lion share of the populations like women and youth. However, there is substantial disparity between men and women regarding access to as well as the use of finance (Ghosh \& Vinod, 2017). Studies show that social recognition and need for achievement is one of the most significant motivating factors for the success of women entrepreneurs (Alam et al., 2011).

As the economy is a developing one, the existing infrastructure facility is not well-equipped for providing job opportunity to this sector of the labor force. Regarding financial access, Zins and Weill (2016) found that being a man, richer, more educated and older favor financial inclusion with a higher influence of education and income. Moreover, some socio-cultural factors impede the development of women entrepreneurs. A research of ILO found that socio-cultural impediments result in family's reluctance to finance women venture, banker's reluctance to take risk of women entrepreneur's venture, and not accepting women as a decision maker and guarantor of the loan to others (N. A. Karim, 2001). However, women encounter two disadvantages: i) they lack confidence in their own ability and ii) society's lack of confidence on women's ability (Amzad et al., 2009).

A country's development is accelerated with the empowerment of women. The best way to empower women is to provide them equal access to factors of production like land, labour, capital and technology as well as unrestricted access to financing sources 
and market information. Research indicates that the major challenges they have to deal with in starting their venture are lack of information, limited business support, lack of confidence, balancing of family and business workload, and acceptance from society (Aktaruddin, 1999). Research on microenterprise owned by women identified independence in working and family problem as the internal factors and access to market information, credit, training, membership in different development organization and infrastructure facilities as the external factors, which remain as the influential issues for the women's involvement in microenterprise (Parvin et al., 2012).

\section{Barriers to financial inclusion in Bangladesh: Women entrepreneurs perspective}

In Bangladesh, development of entrepreneurship is a challenging phenomenon. Besides, women are lag behind in social and economic aspects than men (Hoque \& Itohara, 2009). Women entrepreneurs of Bangladesh have all the potentiality to undertake risk and establish a new venture, yet still they are underprivileged because of their unawareness, illiteracy, unorganized representation, rigid social custom, religious constraints and dominance from male counterparts (Afrin et al., 2008; Tambunan, 2009). These factors impede women contribution to socio-economic development of the country.

Research on problems and challenges of the women entrepreneurs of developing countries reflects that unfavourable business environment, lack of support from credit providers, lack of skill developing training and market information, risk aversion, managerial competency, and family responsibility are crucial determinants for women entrepreneurship development (Bhuiyan \& Abdullah, 2007; Shah \& Mustafa, 2014). A research on factors influencing women business development found that women involvement in business influenced by financial independence and self-fulfilment, father/spouse's occupation, responsibility for children, access to financial resources or start-up capital whereas religion is a less influential factor (Amzad et al., 2009). A study on the problem faced women entrepreneurs of Pakistan found that the shortage of working capital is a highly pronounced problem followed by a shortage of fund for expansion and repayment of the loan (Ullha et al., 2012). Some studies have been conducted on the availability of support services for women. Women entrepreneurs of Bangladesh expect marketing, legal or statutory, technology support, business management and access to financial services among which access to finance is highly pronounced (Morshed, 2008).

Many literatures have found that women entrepreneurs of Bangladesh are struggling with different external and internal complexities. Limited access to financial sources is one of the prevailing issues they have to deal with. Studies demonstrate that women principally recourse to personal saving and family finance rather than the loan from a commercial bank (Coleman, 2000; Orhan, 2001).A fair number of research shows that women are intended to use internal equity source of financing than external sources (Chaganti et al., 1995). Women's less reliance on external financing or bank loan results from the higher rejection of their loan application than their male counterparts. Orhan (2001) found that women were asked for higher collateral, higher interest and other strict terms than male counterparts. Normally, women-owned business is small in size and requires a small amount of start-up capital which is less appealing for potential financer.

Some authors posit that weak business track record, undeveloped owner's credit history and absence of collateral are seen as important by the women entrepreneurs for 
their denial of loan request (Sara \& Peter, 1998). Research on women entrepreneurs' competencies in financial and managerial side found that the lack of financial and managerial competencies hinder their ability to get a bank loan (Green \& Cohen, 1995; Haines et al., 1999). Some researchers argue that due to being uninformed about different financial sources and less representation in financial network women face great difficulty in getting lower cost sources of finance(Greene et al., 2001; Heidrick \& Nicol, 2002). Some studies also discuss that women entrepreneurs are mistreated by financial institutions (Buttner \& Rosen, 1992). Family responsibility and business responsibility lead to women's less reliance on the bank loan and bankers' mistrust about women entrepreneurs (Sara \& Peter, 1998).

Some research show that there is no relation between gender of the firm's owner and financial institutions' intention to finance. Moreover, women-owned venture's firm-specific characteristics and strategic choices influence their choice of financing alternatives (Constantinidis et al., 2006).

Several literatures and reports on the financing of women entrepreneurs of Bangladesh show that there is a rising trend in the financing of women entrepreneurs. According to 2001 census, about $50 \%$ of the people of Bangladesh are female. Labor Force Survey shows that female labor force participation rate is $33.5 \%$ and in the urban area it is $32.9 \%$ and in the rural area, it is $33.7 \%$ (BER, 2016). Participation of the women in the business or any kind of decision making is limited. However, as the new generation is highly motivated and inspired for self-employment, a rising trend is found in the women's involvement in business. Bangladesh Government has taken initiatives to enhance the self-employment rate of women. Microcredit Programme for Self-employment of Women is one of those initiatives that allocated BDT 2.5 crore in 2015-16 fiscal year (BER, 2016). Commercial bank and the specialized bank were also implementing microcredit programme for creating self-employment. Under this programme, the total number of beneficiaries was 18,62,385 among which female were 13,02,812 as of June 2016 (BER, 2016). Bangladesh Bank report showed that SME financing by the bank and non-bank financial institutions were BDT 4226.99 crore in 2015 which is 3.64\% of total and BDT 5345.66 crore in 2016 which is $3.77 \%$ of the total (BER, 2016).

There is still a gap in the demand by women entrepreneurs for financing and supply of finance by the commercial banks and NGOs. This study focuses on the women entrepreneurs' perception of the loan and other services provided by the commercial banks. Understanding the perception of the women entrepreneurs is important for the successful empowerment of women. Several techniques were used to understand the perception. This qualitative research allows deeper exploration of consumers' perception (Jervis \& Drake, 2014) and requires less training session among the respondents. Sometime projective techniques were used for applying unstructured stimuli or stimulus to get the respondent opinions about the situation (Donoghue, 2000). Focus Group discussion is most effective and time-consuming technique to get the customer insight (Carey, 2015). This method was based on group meeting in a friendly environment to gather target audience concept, attitude, and opinion about any product.

The present study used quantitative approach using a structured questionnaire to find out the factors influential in the development of the perception of women entrepreneurs towards the commercial banks. However, this study was also conducted based on in-depth interviews of selected respondents and KII from women entrepreneurs of 
the Sylhet district to get more insights into the problems they dealt with, supporting services they expected, terms and conditions and requirements they needed to meet up when they seek financing from the commercial bank.

\section{Objectives}

The broad objective of the study is to investigate women entrepreneurs' perception of loans of the commercial bank as a source of capital/finance. This major objective has some specific objectives. These are -

i. To find out the factors influential in developing women entrepreneur perception towards commercial bank in getting access to the bank loan.

ii. To provide insights on women entrepreneurs opinion about the problems in their access to finance and facilities that they expect from commercial banks through indepth interviews and KII.

\section{Research methodology}

\section{Sample size and data collection procedure}

The study is conducted among the women entrepreneurs operating their business in Sylhet District, the largest north-eastern district of Bangladesh. The list of the entrepreneurs was collected from the different commercial banks providing the loan to women entrepreneurs, Sylhet Women Chamber of Commerce and Industries (SWCCI), Divisional Office of Bangladesh Women Chamber of Commerce and Industries (BWCCI), and Sylhet Chamber of Commerce and Industries (SCCI). However, there might be some women entrepreneurs who are not listed in any such organization are excluded in the study. Hence, the population size is unknown. The study is conducted among 152 women entrepreneurs doing business in the Sylhet district based on a random sampling. Data were collected in both quantitative and qualitative form. The use of qualitative method of data collection is relevant here. Since the study focuses on the perception of women entrepreneurs, qualitative data (e.g. in-depth interview, KII) can reveal more significant findings (Kelle, 2006). Quantitative data was collected by using a close-ended questionnaire. However, the qualitative data was collected by using in-depth interviews of 15 respondents selected purposively and the Key Informant Interviews (KII) of three women chamber leaders. In the findings part, the interviewees are represented by the symbols E1 to E15. The respondents for the in-depth interview were selected depending on their performance in business sector (success or failure) and position in different organizations (BWCCI \& SWCCI). The interviews were conducted in local language and then transcribed into English. The qualitative data was analysed using content analysis. The rationale behind the use of mixed method was to obtain a more realistic perception of access to bank credit (Palinkas et al., 2015). Because, in-depth interviews reveal individual observations and experiences that might have a significant impact on policy formulation (Carter et al., 2014).

\section{Measurement instrument}

A close-ended questionnaire was prepared for data collection purpose which had three parts- demographic profile, business profile and opinion on access to finance. The third portion of the questionnaire is prepared using 5-point Likert Scale (Likert, 1972) 
(where $1=$ strongly disagree and $5=$ strongly agree). The variables of the questionnaire were selected focusing on the findings of different literature especially those works focusing on the access to finance (Amzad et al., 2009; Constantinidis et al., 2006) by the women entrepreneurs.

\section{Data analysis tools}

The data was analyzed in two parts. The first part analyzed quantitative data that shows women entrepreneurs demographic information, business information and the factors influencing their perception about bank finance. To find out the influential factor (Table 1) Exploratory Factor Analysis (EFA) was conducted. The Cronbach's Coefficient $(\alpha)$ was run to test the reliability of the data. The SPSS 20.0 software was used to analyze the data. The second part of the data analysis represent the opinion of the women entrepreneurs in the in-depth interview and the observations from KII. Fifteen women entrepreneurs were selected for the in-depth interview. To analyze such qualitative data, the researchers first recorded the interviews and then transcribed them into English. Later on, the summary of the major issues raised in the interviews regarding access to bank credit was discussed in the findings part of the study report.

Table 1 Demographics of survey respondents

\begin{tabular}{|c|c|c|c|}
\hline Characteristic & Category & Frequency & Percentage \\
\hline \multirow[t]{4}{*}{$\overline{\text { Age }}$} & $21-30$ & 48 & 31.6 \\
\hline & $31-40$ & 50 & 32.9 \\
\hline & $41-50$ & 44 & 28.9 \\
\hline & above 50 & 10 & 6.6 \\
\hline \multirow[t]{4}{*}{ Religion } & Muslim & 120 & 78.9 \\
\hline & Hindu & 26 & 17.1 \\
\hline & Christian & 4 & 2.6 \\
\hline & Others & 2 & 1.3 \\
\hline \multirow[t]{2}{*}{ Marital Status } & Married & 116 & 76.3 \\
\hline & Unmarried & 36 & 23.7 \\
\hline \multirow[t]{2}{*}{ Family Type } & Nuclear & 98 & 64.5 \\
\hline & Joint Family & 54 & 35.5 \\
\hline \multirow[t]{7}{*}{ Education } & Literate & 4 & 2.6 \\
\hline & Primary & 4 & 2.6 \\
\hline & Junior & 26 & 17.1 \\
\hline & SSC & 42 & 27.6 \\
\hline & HSC & 20 & 13.2 \\
\hline & Graduate & 32 & 21.1 \\
\hline & Masters & 24 & 15.8 \\
\hline \multirow[t]{5}{*}{ Previous Experience } & Private Job & 44 & 28.9 \\
\hline & Govt. Job & 6 & 3.9 \\
\hline & Family Business & 16 & 10.5 \\
\hline & Unemployed & 66 & 43.4 \\
\hline & Others & 20 & 13.2 \\
\hline
\end{tabular}




\section{Results and discussion}

\section{Demographic and business characteristics}

Most of the time women start their business at the age when they have family and children (Green \& Cohen, 1995; Mwobobia, 2012; Zororo, 2011). The demographic results of the study showed that most of the women entrepreneurs are young and their age range from 21 to 40 years (Table 2).

At this age most of the people especially women have the energy and confidence to take risk of doing business. According to GEM (2011) in Bangladesh 25-34 and 35-44 age groups show high entrepreneurial activity which declines with age.

The study found that most of the entrepreneurs are educated like 27.6\% are SSC pass, $13.2 \%$ are HSC pass, $21.1 \%$ are graduate and $15.8 \%$ are masters completed. The previous experience of the entrepreneurs showed that the highest percentage that is $43.4 \%$ are unemployed and second highest $28.9 \%$ were involved in the private job.

The study found that maximum of the venture run by women is the micro and small enterprise which is almost $90.8 \%$. This is because of the lack of capital accumulation by the women entrepreneurs, they could not start up large ventures other than micro enterprises. Startup capital enables a firm to acquire assets, pay for daily operating expenses and reliance for any unforeseen events. Normally, women-owned ventures are known for low start-up and working capital (Green \& Cohen, 1995), which hinder their ability to take high risk and reduce growth potentiality. According to GEM (2011), $6.2 \%$ of female entrepreneurs strongly agree that they had sufficient amount of start-up capital. The current study found that to start the business, $75 \%$ of the women relied on own fund and family finance and very few (8.9\%) get a loan from the commercial bank to start the business. The women entrepreneurs have to face a great hurdle in getting access to finance due to lack of information, collateral, discriminatory laws (Common Wealth Secretary 2002) guarantor, and experience. This study revealed that $21 \%$ women

Table 2 Business characteristics and financing

\begin{tabular}{llll}
\hline Characteristic & Category & Frequency & Percentage \\
\hline Business size (Employee) & Zero & 6 & 3.9 \\
& $1-9$ & 102 & 67.1 \\
& $10-49$ & 36 & 23.7 \\
& $50-99$ & 4 & 2.6 \\
Source of initial capital & Above 100 & 4 & 2.6 \\
& Own Fund & 68 & 44.7 \\
& Family Finance & 30.3 \\
& Personal Loan & 46 & 5.3 \\
& Business Loan & 8 & 2.6 \\
& Loan from NGO & 4 & 3.9 \\
& Both self \& bank loan & 6 & 10.5 \\
& Loan from other institution & 16 & 2.6 \\
& Received Full Amount & 4 & 21.0 \\
& Less than Full Amount & 32 & 46.1 \\
& Applied but not get & 70 & 32.9 \\
\hline
\end{tabular}

Source: Field Survey 
entrepreneurs get the full amount of loan that they had applied and $46.1 \%$ get less than the applied amount whereas $32.9 \%$ had applied but not received due to lack of collateral, guarantor, experience (Table 3).

\section{Exploratory factor analysis (EFA)}

The data were analyzed based on the principal components factor analysis to find out the factors that could affect the perception of women entrepreneurs about the bank loan. From the analysis preliminarily eight factors were identified $(67.6 \%$ of the variance) as the influential factor. Among these eight factors, finally, 4 factors were considered as significant as at least three variables poses loading value of 0.50 above, one was rejected as it represents two categories of factors and three were not included as they have low loading values. The four factors that have extracted from the EFA pose a cumulative variance of $44.667 \%$.

The Cronbach's reliability coefficient $(\alpha)$ for the average extracted factor of the survey is 0.780 which is above the acceptable limit (0.6). The overall matrix of the KMO value is 0.585 (showed in the below Table 4).

In Bartlett's Test of Sphericity, the Chi-square value is estimated 2368.19 which is significant at $5 \%$ level.

\section{Problems faced}

The first influential factor is problems faced by the women entrepreneurs when applying for a loan. This factor included six items noted as P2 (Unnecessary documents), P7 (Felt mistreated), P10 (Loan officers are not well informed about the loan), P6 (Difficult to go refinance), P4 (Officers are not helpful) and P3 (Financial assistance is not sufficient) with $19.04 \%$ variance. The loading of this factor is ranging from 0.625 to 0.829 . Previous studies also focused on the problems faced by the women entrepreneurs more than their male counterparts (Hoque \& Itohara, 2009) in Bangladesh. Yet, in the current study, such discrimination from the gender perspective is not revealed.

\section{Terms and conditions}

The second influential factor is terms and conditions required before applying for a loan by the women entrepreneurs. This factor included five items noted as TC7 (Assets size of the business), TC11 (Market coverage of the business), TC6 (Age of the business a women entrepreneur is engaged in), TC10 (Types of the business operated) and TC8 (Loan limit under different scheme) with variance of $16.060 \%$. The loading of this factor is ranging from 0.534 to 0.785 . Although previous studies reveal some other factors specific to women entrepreneurs development (Bhuiyan \& Abdullah, 2007), the current study found terms and conditions of the bank loan as an important factor.

Table $3 \mathrm{KMO}$ and Bartlett's Test

\begin{tabular}{lll}
\hline Kaiser-Meyer-Olkin Measure of Sampling Adequacy & & 0.585 \\
\hline Bartlett's Test of Sphericity & Approx. Chi-Square & 2368.195 \\
& Df & 378 \\
& Sig. & .000 \\
\hline
\end{tabular}

Source: Authors' calculation 
Table 4 Exploratory Factor Analysis

\begin{tabular}{|c|c|c|c|c|c|c|}
\hline Factor name & Items & $\begin{array}{l}\text { Item } \\
\text { loading }\end{array}$ & Communalities & $\begin{array}{l}\% \text { of variance } \\
\text { (Cumulative) }\end{array}$ & $\begin{array}{l}\text { Cronbach's reliability } \\
\text { coefficient }\end{array}$ & $\begin{array}{l}\text { Eigen } \\
\text { value }\end{array}$ \\
\hline \multirow[t]{6}{*}{ Problems Faced (p) } & P2 & 0.828 & .790 & \multirow[t]{6}{*}{19.039 (19.039) } & \multirow[t]{6}{*}{.845} & \multirow[t]{6}{*}{8.007} \\
\hline & P7 & 0.768 & .640 & & & \\
\hline & P10 & 0.751 & .610 & & & \\
\hline & P6 & 0.728 & .816 & & & \\
\hline & P4 & 0.664 & .586 & & & \\
\hline & P3 & 0.625 & .733 & & & \\
\hline \multirow{5}{*}{$\begin{array}{l}\text { Terms and } \\
\text { conditions (TC) }\end{array}$} & TC 7 & 0.785 & .783 & \multirow[t]{5}{*}{$16.060(35.099)$} & \multirow[t]{5}{*}{.818} & \multirow[t]{5}{*}{6.754} \\
\hline & $\begin{array}{l}\mathrm{TC} \\
11\end{array}$ & 0.771 & .720 & & & \\
\hline & TC6 & 0.741 & .691 & & & \\
\hline & $\begin{array}{l}\mathrm{TC} \\
10\end{array}$ & 0.686 & .742 & & & \\
\hline & TC 8 & 0.534 & .754 & & & \\
\hline \multirow[t]{3}{*}{ Business Profile (BP) } & BP3 & 0.829 & .815 & \multirow[t]{3}{*}{$9.568(44.667)$} & \multirow[t]{3}{*}{.850} & \multirow[t]{3}{*}{4.024} \\
\hline & BP4 & 0.765 & .700 & & & \\
\hline & BP5 & 0.636 & .685 & & & \\
\hline \multirow{3}{*}{$\begin{array}{l}\text { Collateral } \\
\text { Requirements (CR) }\end{array}$} & CR2 & 0.771 & .729 & \multirow[t]{3}{*}{6.042 (57.698) } & \multirow[t]{3}{*}{.850} & \multirow[t]{3}{*}{2.541} \\
\hline & CR9 & 0.679 & .671 & & & \\
\hline & CR1 & 0.612 & .825 & & & \\
\hline
\end{tabular}

Source: Authors' calculation

\section{Business profile}

The third influential factor is business profile that banks want to know before approving a loan to the women entrepreneurs. This factor included three items noted as BP3 (High business profit of the entrepreneur), BP4 (cash flow of the business) and BP5 (location of the business) with a variance of $9.564 \%$. The loading of this factor is ranging from 0.636 to 0.829. This aspect of borrowers was also explored in the study conducted by Amzad et al. (2009) in a different method. However, (Green \& Cohen, 1995) in their study revealed lack of financial and managerial competencies hinder the ability of women entrepreneurs to get a bank loan. However, women-owned ventures' firm-specific characteristics and strategic choice also influence their preference for financing alternatives (Constantinidis et al., 2006).

\section{Collateral requirements}

The fourth influential factor is termed as collateral requirement of a loan applied by the women entrepreneurs. This factor included three items noted as CR2 (Quality/Types of collateral required by the bank), CR9 (Experience of the entrepreneur) and CR1 (Importance of collateral required by the bank) with a variance of $6.042 \%$. The loading of this factor is ranging from 0.612 to 0.771 . This factor is matched with the study conducted by Sara and Peter (1998).

\section{Findings from in-depth interview and KIls}

Findings from the in-depth interviews and KII (Key Informant Interviews) adds value to the quantitative finding of the study. Some more issues have been retrieved related 
to women entrepreneurship through qualitative analysis apart from the EFA. Opinions from the women entrepreneurs and chairmen of three Women Chamber of Commerce are summed up below:

\section{Hidden cost}

Some participants of the interviews said that though some loan processing charges are removed by the Bangladesh Bank for the women entrepreneur, commercial bank charges it indirectly that incurs a hidden cost.

"As far we know loan processing charges are not applied on the loan specialized for women entrepreneurs. We have argued with the banker but there is no result other than paying those charges. Ultimately these costs increase the loan interest rate by 6 to 7 percent more (E2 \& E4) ".

Such narration by the respondents reveals the hidden cost of loan from banks faced by women entrepreneurs.

\section{High-interest rate}

Few women entrepreneurs opined that some commercial bank charge 6 to $7 \%$ more interest rate than the stated interest rate. The loan officers are not able to show strong standing about this other than indicating to the head office. The description shared by $\mathrm{E} 2$ and E4 can be related to this issue.

\section{Collateral}

Some other respondents had the feeling that bank take unnecessary collateral against a loan from the entrepreneurs as well as evaluation fee for the collateral is also charged from the borrowers.

"I have come from middle income family and have no inherited land property from my father. I am running my business in a rented premises. I had tried to get loan from commercial banks but they were very reluctant to grant the loan without land as collateral (E9)."

Instead of land as a collateral, banks do not have different mode of collateral so that such entrepreneurs could have access in bank credit. This finding of the study from in-depth interview substantiates the results from EFA.

\section{Guarantor}

Banks do not trust the competencies of the women entrepreneurs said by the chairman of BWCCI, Sylhet Division (KII-1). That is why commercial banks need guarantors with good financial conditions with at least one government job holder. N. A. Karim (2001) also concluded the importance of guarantor in his study.

“When you are a women banks don't grant you loans, since they think you are not credible to get loan. Being a women, it creates a negative impression to the banker. Moreover, sometimes they require government officer as a guarantor of the loan (E7)." 
From the above expression, although guarantor of loan is essential, women entrepreneurs become reluctant to access in bank credit. As per EFA findings, terms and conditions for loan is a significant problem faced by the women entrepreneurs, KII- 1 also justifies the quantitative results.

\section{No unique roles and regulations}

Some entrepreneurs stated that some commercial banks do not follow the guidelines of the Bangladesh Bank while granting credit to women entrepreneurs. Most of the time they follow their own policies showing less concern about central bank policies.

\section{Relation with the banker}

Some women entrepreneurs said that they easily get a loan from the bank because of the husband's acquaintance with the banker as well as for family reputation. This type of barrier can be termed as the lack of confidence (Amzad et al., 2009) of the bankers regarding women entrepreneurs financing in general. According to EFA, collateral requirements is another problem to the women entrepreneurs. Likewise, relationship with bankers serves as a collateral.

"I didn't face any problem neither I need to show many documents to get the loan. My husband is also a businessman and has very good relation with the banker that is why I didn't have any hardship to get the loan. In fact, they encourage me to take more loan (E3)."

Her experience is almost polar opposite to E7 regarding guarantor and accessing bank credit. However, in E7 views, banks actually provide loan based on the credibility of repayment by the borrower. Having good relationship with bankers ensures credibility.

\section{Loan scheme}

Another opinion comes from the women entrepreneurs that the loan limit and attached interest rate are not supportive to the financing needs of the entrepreneurs.

"I have searched several loan scheme specialized for women entrepreneurs. I didn't get any scheme matched with my requirement or I feel that I should go for it. The loan amounts are either too high or too small (E12)."

In her opinion, rigidity in loan schemes is also an obstacle that discourages women entrepreneurs to access in bank credit.

\section{Risk aversion}

Some women entrepreneurs mentioned that they rely on the own business profit and family finance instead of applying for the bank loan because of the fear of being refused by the bank and loss of independence in decision making. 
"My business is running well and all my family members are working in my business. I always rely on business profit and family financing. I didn't apply for any bank loan because I fear that bank may refuse my application (E5)."

Some previous studies also focused on the risk aversion characteristics of the entrepreneurs (Bhuiyan \& Abdullah, 2007; Shah \& Mustafa, 2014).

\section{Supporting facility}

Some of the participating women entrepreneurs pointed out that they expect commercial banks to provide some supporting services like training, information about market entry and different financing sources especially for new entrepreneurs.

\section{Absent of loan for new entrepreneurs}

One young woman entrepreneurs thriving for finance opined that she was rejected by a commercial bank as she had no business track record and bank had no special loan for the new start-ups.

"I am a young entrepreneur and have come up with a very new concept of delivering organic food to the city dwellers. The bank requires past track record of the business in granting loan. As I am very new in that line, I have no previous experience and that is why I am not getting any loan (E15)."

Although she had a new business idea, the bank she applied for loan might not have enough knowledge about the prospects of the business and also the entrepreneurial capacity of the applicant. Eventually, she was rejected to provide loan and a new venture did not find the light of hope.

\section{Lengthy and time-consuming process}

From her personal experience a woman entrepreneur said that she had to wait for one and a half year to get the loan from a commercial bank after several times of rejections and investigation.

"I am a divorced women with one child. I am the earning member of my family. Sometime my mother helped me in my business. I have applied for a loan one and half years ago. The loan officer had visited my business premises several times and asked for fresh requirements each time. I have completed all the requirements but still didn't get the loan (E8). "

It seems from her observation that the loan provision takes more time. However, the loan officer visited the site but he might not get enough confidence to provide her loan.

\section{Ambiguity in application form}

The chairmaijn of the SWCCI (KII-2) who is an entrepreneur pointed out that many women entrepreneurs are not familiar with the English language where the loan application form is in English. Most of the time they signed the agreement 
without understanding the terms and conditions of the loan and later they think that they were cheated by the bank.

\section{Conclusion}

Women entrepreneurs are providing the ever-increasing contribution to the economy of Bangladesh. The current study attempted to find out the opinion of the women entrepreneurs regarding the problem they faced in getting finance, requirements, terms and conditions, and business characteristics they need to meet up to get access to finance. The study also showed focus group opinion about the availability of bank financing, interest rate, banking environment and attitude of the bankers. The findings of the study can help the commercial bank in formulating their strategic decision about financing women entrepreneurs. This study also indicates some paths for the authoritative and supporting organizations of women entrepreneurs to reorganize their action plans for supporting the women entrepreneurs.

\section{Limitation and scope of further research}

The study offers a number of useful insights into different critical phenomena, yet it has some limitations as well. Firstly, the study was conducted on women entrepreneurs of Sylhet city, not on the whole Sylhet Division or the whole country. Additionally, limitations come from the respondents of the survey. According to the definition of an entrepreneur, he/she must take all the responsibility of doing business and assume the risk. The study found three categories of entrepreneurs whose status as an entrepreneur was subject to question. Some women entrepreneurs did not start business by herself but sit on husbands or family business, some women entrepreneurs who are the legal owner of the firm, but all the legal and financial activities are performed by husband/brother, and lastly some women entrepreneurs have become owner of their husband's business to reduce the tax burden or get loan at a low interest rate for her husband. Thus, there is a scope for future research on that features of women entrepreneurs in the whole country. 


\section{Author details}

'Department of Business Administration, Sylhet International University, Sylhet, Bangladesh. ${ }^{2}$ Department of Economics \& Banking, International Islamic University Chittagong, Chittagong, Bangladesh.

Received: 14 April 2018 Accepted: 8 November 2018

Published online: 28 November 2018

\section{References}

Afrin, S., Islam, N., \& Ahmed, S. U. (2008). A multivariate model of micro credit and rural women entrepreneurship development in Bangladesh. International Journal of Business and Management, 3(8), 169-185.

Aktaruddin, M. (1999). A case study of some successful and unsuccessful entrepreneurs in Bangladesh. Journal of Business Administration, 25(1\&2), 89-126.

Alam, S. S., Jani, M. F. M., \& Omar, N. A. (2011). An empirical study of success factors of women entrepreneurs in southern region in Malaysia. International Journal of economics and Finance, 3(2), 166.

Amzad, H., Kamal, N., Asif, Z., \& Rana, N. (2009). Factors influencing women business development in the developing countries: Evidence from Bangladesh. International Journal of Organizational Analysis, 17(3), 202-224. https://doi. org/10.1108/19348830910974923.

Asuming, P. O., Osei-Agyei, L. G., \& Mohammed, J. I. (2018). Financial inclusion in sub-Saharan Africa: Recent trends and determinants. Journal of African Business, 1-23. https://doi.org/10.1080/15228916.2018.1484209.

Barber, K. (1998). The Canadian Oxford dictionary. Toronto: New York: Oxford University Press.

Bangladesh. Parisaṃkhyāna Byuro. (2016). Statistical yearbook of Bangladesh. Bangladesh Bureau of Statistics, Statistics Division, Ministry of Planning, Government of the People's Republic of Bangladesh.

Bhuiyan, M. B., \& Abdullah, R. (2007). Women empowerment through entrepreneurship development: Bangladesh perspective. Daffodil International University Journal of Business and Economics, 2(2).

Buttner, E. H., \& Rosen, B. (1992). Rejection in the loan application process: Male and female entrepreneurs' perceptions and subsequent intentions. Journal of Small Business Management, 30(1), 58.

Carey, M. A. (2015). Focus group International Encyclopedia of the Social \& Behavioral Sciences (2nd ed.pp. 274-279). Oxford, UK: Elsevier.

Carter, N., Bryant-Lukosius, D., DiCenso, A., Blythe, J., \& Neville, A. J. (2014). The use of triangulation in qualitative research. Paper presented at the Oncology nursing forum.

Chaganti, R., DeCarolis, D., \& Deeds, D. (1995). Predictors of capital structure in small ventures. Entrepreneurship Theory and Practice, 20(2), 7-18.

Coleman, S. (2000). Access to capital and terms of credit: A comparison of men-and women-owned small businesses. Journal of Small Business Management, 38(3), 37.

Constantinidis, C., Cornet, A., \& Asandei, S. (2006). Financing of women-owned ventures: The impact of gender and other owner -and firm-related variables. Venture Capital, 8(2), 133-157. https://doi.org/10.1080/13691060600572557.

Donoghue, S. (2000). Projective techniques in consumer research. Journal of Consumer Sciences, 28(1).

Finance Division (2016). Bangladesh Economic Review, Ministry of Finance, Government of the People's Republic of Bangladesh.

Gartner, W. (1988). Who is an entrepreneur? Is the wrong question. American Journal of Small Business, 12(4), 11-32.

GEM. (2011). Bangladesh 2011 Monotoring report. In G. E. Monitor (Ed.).

Ghosh, S., \& Vinod, D. (2017). What constrains financial inclusion for women? Evidence from Indian micro data. World Development, 92, 60-81. https://doi.org/10.1016/j.worlddev.2016.11.011.

Green, E., \& Cohen, L. (1995). 'Women's business': Are women entrepreneurs breaking new ground or simply balancing the demands of 'women's work' in a new way? Journal of Gender Studies, 4(3), 297-314. https://doi.org/ 10.1080/09589236.1995.9960615.

Greene, P. G., Brush, C. G., Hart, M. M., \& Saparito, P. (2001). Patterns of venture capital funding: Is gender a factor? Venture Capital, 3(1), 63-83. https://doi.org/10.1080/13691060118175.

Haines, G. H., Orser, B. J., \& Riding, A. L. (1999). Myths and realities: An empirical study of banks and the gender of small business clients. Canadian Journal of Administrative Sciences / Revue Canadienne des Sciences de l'Administration, 16(4), 291-307. https://doi.org/10.1111/j.1936-4490.1999.tb00690.x.

Heidrick, T., \& Nicol, T. (2002). Financing SMEs in Canada: Barriers Faced by Women, Youth, Aboriginal and Minority Entrepreneurs in Accessing Capital-Phase 1: Literature Review. Ottawa: Public Works and Government Service Canada.

Hirsch, R. D., \& Peters, M. P. (1989). Entrepreneurship: Starting, developing and managing a new enterprise. PIP Irwin Homewood: Illinois USA.

Hoque, M., \& Itohara, Y. (2009). Women empowerment through participation in micro-credit programme: A case study from Bangladesh. Journal of Social Sciences, 5(3), 244-250.

Jervis, M., \& Drake, M. (2014). The use of qualitative research methods in quantitative science: A review. Journal of Sensory Studies, 29(4), 234-247.

Karim, N. A. (2001). Jobs, gender and small enterprises in Bangladesh: factors affecting women entrepreneurs in small and cotage industries in Bangladesh. Retrieved from http://www.lo.org/public/libdoc/ilo/2001/101B09_96_engl.pdf

Karim, R., \& Chowdhury, T. (2014). Customer satisfaction on service quality in private commercial banking sector in Bangladesh. British Journal of Marketing Studies, 2(2), 1-11.

Kelle, U. (2006). Combining qualitative and quantitative methods in research practice: Purposes and advantages. Qualitative Research in Psychology, 3(4), 293-311. https://doi.org/10.1177/1478088706070839.

Likert, R. E. N. S. I. S. (1972). Likert technique for attitude measurement. Social Psychology: Experimentation, Theory, Research, Sahakian, WS (Ed.). Intext Educational Publishers, Scranton, USA., ISBN-13, 1059690887, 101-119.

Morshed, S. F. (2008). Challenges and opportunities for women SMEs in Bangladesh. In 2nd National SME Women Entrepreneurs Conference on Empowering Women Entrepreneurs Towards a Shared Economic Growth, SME Foundation. Dhaka.

Mwobobia, F. M. (2012). Role of business management into the success and survival of small businesses: The case of star learning Centre in Botswana. International Journal of Business Administration, 3(1), 93-112. 
Nguyen, C., Islam, A., \& Ali, M. M. (2011). The current state of the financial sector of Bangladesh: An analysis. American International University-Bangladesh, Office of Research and Publications (ORP).

Orhan, M. (2001). Women business owners in France: The issue of financing discrimination. Journal of Small Business Management, 39(1), 95-102. https://doi.org/10.1111/0447-2778.00009.

Palinkas, L. A., Horwitz, S. M., Green, C. A., Wisdom, J. P., Duan, N., \& Hoagwood, K. (2015). Purposeful sampling for qualitative data collection and analysis in mixed method implementation research. Administration and Policy in Mental Health and Mental Health Services Research, 42(5), 533-544.

Panvin, L., Rahman, M. W., \& Jia, J. (2012). Determinates of women micro-entrepreneurship development: An empirical investigation in rural Bangladesh. International Journal of Economics and Finance, 4(5), 254. https://doi.org/10.5539/ijef.v4n5p254.

Sara, C., \& Peter, R. (1998). The financing of male- And female-owned businesses. Entrepreneurship \& Regional Development, 10(3), 225-242. https://doi.org/10.1080/08985629800000013.

Shah, F. A., \& Mustafa, Z. (2014). Prospects of women entrepreneurship: A study of the women entrepreneurs of Kashmir valley. Arth prabandh: A. Journal of Economics and Management, 3(1), 103-116.

Tambunan, T. (2009). Women entrepreneurship in Asian developing countries: Their development and main constraints. Journal of Development and Agricultural Economics, 1(2), 027-040.

Ullha, H., Ahmad, Z. M., Manzoor, S. R., Hussain, M., \& Farooq, M. A. (2012). Problems faced by women entrepreneurs in Kohat city of Khyber Pakhtunkhwa-Pakistan. International Journal of Human Resource Studies, 2(1), 1.

Zins, A., \& Weill, L. (2016). The determinants of financial inclusion in Africa. Review of Development Finance, 6(1), 46-57. https:// doi.org/10.1016/j.rdf.2016.05.001

Zororo, M. (2011). Characteristics and motivation in female entrepreneurship. In Case of Botswana. University of Botswana Journal.

Submit your manuscript to a SpringerOpen ${ }^{\odot}$ journal and benefit from:

- Convenient online submission

- Rigorous peer review

- Open access: articles freely available online

- High visibility within the field

- Retaining the copyright to your article

Submit your next manuscript at $\boldsymbol{\nabla}$ springeropen.com 